\title{
Vitamin D Deficiency in Rheumatoid Arthritis and Vitamin D Levels that vary with Rheumatoid Arthritis Severity: An Indian Study
}

\author{
${ }^{1}$ Muzamil Latief, ${ }^{2}$ Farhat Abbas, ${ }^{3}$ Amandeep Minhas, ${ }^{4}$ Waseem Dar, ${ }^{5}$ Manzoor Parry, ${ }^{6}$ Purshotam D Gupta
}

\begin{abstract}
Introduction: Rheumatoid arthritis (RA) is an autoimmune disease characterized by periods of remission and flares of symmetrical joint inflammation slowly progressing to joint and cartilage destruction leading to deformities. Evidence is accumulating suggesting vitamin $\mathrm{D}$ deficiency and its correlation in autoimmune diseases including RA.
\end{abstract}

Aims of study: (1) Estimation of vitamin D levels in RA patients. (2) Correlation of vitamin D levels with severity of the disease.

Materials and methods: A study population of 50 included 25 cases and 25 controls. Both males and females of 30 to 40 years of age were taken for this study. Patients of RA having any other autoimmune disease were excluded. Twenty-five healthy adults, whose ages were between 30 and 40 years, both male and female, free from any systemic illness were taken as controls. Routine systematic examination and detailed joint examination were done. Disease activity was measured in patients of RA according to Disease Activity Score (DAS-28). Erythrocyte sedimentation rate (ESR), C-reactive protein (CRP), rheumatoid factor (RF), and anticyclic citrullinated peptide (CCP) among other routine blood investigations were done.

Results: In cases, the mean vitamin D level was $18.41 \mathrm{ng} / \mathrm{mL}$ with standard deviation (SD) of 7.10 , while controls had mean level as $22.32 \mathrm{ng} / \mathrm{mL}$ with SD as 4.80. The difference between the two was recorded as statistically significant, i.e., p-value $<0.05$. While $4(16.0 \%)$ patients had low severity, $15(60.0 \%)$ had moderate severity, and $6(24.0 \%)$ patients had high severity of disease as per DAS-28. Patients whose RA disease activity was high had lower vitamin $D$ levels.

Conclusion: It is thus concluded that in RA patients the serum vitamin $D$ levels are significantly lower than in healthy control, and vitamin $\mathrm{D}$ deficiency may be one of the causes contributing to worsening of RA.

\footnotetext{
${ }^{1,5}$ Senior Resident, ${ }^{2}$ Resident, ${ }^{3}$ Postgraduate Resident ${ }^{4}$ Consultant, ${ }^{6}$ Professor

1,3,5,6 Department of Medicine, Maharishi Markandeshwar Institute of Medical Sciences \& Research, Maharishi Markandeshwar University, Ambala, Haryana, India

${ }^{2}$ Department of Pathology, Sher-i-Kashmir Institute of Medical Sciences, Srinagar, Jammu and Kashmir, India

${ }^{4}$ Department of Medicine, Sanjeev Bansal Cygnus Hospital Karnal, Haryana, India

Corresponding Author: Muzamil Latief, Senior Resident Department of Medicine, Maharishi Markandeshwar Institute of Medical Sciences \& Research, Maharishi Markandeshwar University, Ambala, Haryana, India, Phone: +919467765499 e-mail: muzamillatief.b@gmail.com
}

Keywords: Disease activity score 28, Rheumatoid arthritis, Vitamin D.

How to cite this article: Latief M, Abbas F, Minhas A, Dar W, Parry M, Gupta PD. Vitamin D Deficiency in Rheumatoid Arthritis and Vitamin D Levels that vary with Rheumatoid Arthritis Severity: An Indian Study. J Postgrad Med Edu Res 2017;51(4):162-165.

\section{Source of support: Nil}

Conflict of interest: None

\section{INTRODUCTION}

Rheumatoid arthritis is an autoimmune disease characterized by periods of remission and flares of symmetrical joint inflammation slowly progressing to joint and cartilage destruction leading to deformities. ${ }^{1}$ The disease commonly affects women of age group 30 to 50 years. Prevalence of RA globally is $0.24 \%$ (95\% confidence interval 0.23 to $0.25 \%){ }^{2}$ The prevalence of RA in Indian population has been estimated to vary from 0.3 to $0.75 \%$. ${ }^{1}$ Evidence is accumulating regarding deficiency of vitamin $\mathrm{D}$ in many autoimmune rheumatic diseases including systemic lupus erythematosus (SLE), RA, etc. ${ }^{3}$ Vitamin $\mathrm{D}$ affects calcium, phosphate, and bone metabolism. ${ }^{4-6}$ Most of the earlier studies indicated low vitamin D levels were a common finding in RA, and in a recent study it was found that higher intake of vitamin $D$ was inversely associated with risk of RA. ${ }^{4}$ Vitamin D deficiency influences immune responses associated with RA. ${ }^{7-9}$ Vitamin $\mathrm{D}$ is synthesized in skin by ultraviolet B rays. Literature suggests correlation between vitamin $\mathrm{D}$ deficiency and several autoimmune disorders, including inflammatory bowel disease, SLE, insulin-dependent diabetes mellitus, multiple sclerosis, and RA. ${ }^{2,3}$

The major source of vitamin $\mathrm{D}$ for humans is exposure to sunlight. ${ }^{3-5,10}$ Vitamin D levels more than $30 \mathrm{ng} / \mathrm{mL}$ are considered to be sufficient. ${ }^{10,11}$ We conducted a study in RA patients attending our tertiary care hospital with the aim to estimate vitamin D levels and correlation of vitamin D levels with severity of RA.

\section{MATERIALS AND METHODS}

The present study was carried out on patients who attended our hospital located in suburban region in India. 
Vitamin D Deficiency in Rheumatoid Arthritis

Total study population was 50 that included 25 cases and 25 controls. Both males and females of 30 to 40 years of age group were taken for this study. Cases were patients of RA diagnosed according to the 1987 revised criteria of the American College of Rheumatology. Patients of RA having any other autoimmune disease were excluded. Also patients with chronic renal failure, diabetes mellitus, patients on enzyme-inducer drugs, or on calcium and vitamin D supplements were excluded from the study. Twenty-five healthy adults whose ages were between 30 and 40 years, both males and females, free from any systemic illness were taken as controls. Detailed history of patients about vitamin D supplements, drug intake, disease onset, extraarticular manifestations, and duration of disease was noted. Routine systematic examination and detailed joint examination were done. Disease activity was measured in patients of RA according to DAS-28. Erythrocyte sedimentation rate, CRP, RF, and anti-CCP among other blood routine blood investigations were done.

\section{RESULTS}

\section{Distribution of Demographic Data}

The distribution shows the mean age, weight, height, and body mass index (BMI) of the studied patient and control population (Table 1).

\section{Investigations}

The investigative profile is shown in Table 2.

\section{Vitamin D Levels in Cases and Controls}

In cases, the mean vitamin D level was $18.41 \mathrm{ng} / \mathrm{mL}$ with SD of 7.10, while controls had mean level as $22.32 \mathrm{ng} / \mathrm{mL}$ with SD as 4.80. The difference between the two was recorded as statistically significant, i.e., p-value $<0.05$ (Table 3 and Graph 1).

\section{Vitamin D Deficiency and Severity of RA according to DAS-28 Score}

While $4(16.0 \%)$ patients had low severity, $15(60.0 \%)$ had moderate severity, and $6(24.0 \%)$ patients had high severity of disease as per DAS-28 score (Table 4):

- DAS-28 score $>5.1$ high disease activity

Table 1: Mean age, weight, height, and BMI of the studied patient and control population

\begin{tabular}{|c|c|c|c|}
\hline \multirow[b]{2}{*}{ Variable } & Cases of RA & Control & \\
\hline & Mean \pm SD & Mean \pm SD & $p$-value \\
\hline Age (years) & $35.36 \pm 3.18$ & $34.52 \pm 3.17$ & 0.352 \\
\hline Weight (kg) & $57.44 \pm 9.36$ & $57.20 \pm 9.82$ & 0.930 \\
\hline Height $(\mathrm{cm})$ & $158.48 \pm 7.64$ & $158.32 \pm 6.61$ & 0.937 \\
\hline BMI $\left(\mathrm{kg} / \mathrm{m}^{2}\right)$ & $23.10 \pm 4.88$ & $22.91 \pm 4.39$ & 0.888 \\
\hline
\end{tabular}

Table 2: Investigation profile of the study population

\begin{tabular}{|c|c|c|c|}
\hline Variable & $\begin{array}{l}\text { Case, mean } \\
\pm S D\end{array}$ & $\begin{array}{l}\text { Control, mean } \\
\pm S D\end{array}$ & $p$-value \\
\hline Hemoglobin & $10.52 \pm 1.54$ & $12.08 \pm 1.91$ & $<0.001$ \\
\hline $\begin{array}{l}\text { Platelet count }\left(10^{5}\right. \\
\left.\text { cells } / \mathrm{mm}^{3}\right)\end{array}$ & $2.64 \pm 0.63$ & $2.73 \pm 0.63$ & 0.622 \\
\hline White blood cell (count) & $6.83 \pm 1.71$ & $5.81 \pm 1.67$ & 0.038 \\
\hline $\mathrm{CRP}(\mathrm{mg} / \mathrm{L})$ & $3.70 \pm 1.35$ & $2.92 \pm 1.40$ & 0.051 \\
\hline ESR (mm/1st hour) & $29.60 \pm 7.24$ & $14.64 \pm 2.41$ & $<0.001$ \\
\hline Creatinine (mg/dL) & $0.87 \pm 0.23$ & $0.70 \pm 0.25$ & 0.022 \\
\hline Red blood cell (mg/dL) & $134.24 \pm 9.21$ & $134.44 \pm 9.10$ & 0.939 \\
\hline Serum calcium (mg/dL) & $8.23 \pm 0.80$ & $8.74 \pm 0.72$ & 0.021 \\
\hline Serum phosphate (mg/dL) & $3.37 \pm 0.61$ & $3.45 \pm 0.62$ & 0.649 \\
\hline Uric acid & $4.46 \pm 0.86$ & $3.18 \pm 0.78$ & $<0.001$ \\
\hline Vitamin D level & $15.06 \pm 6.35$ & $22.32 \pm 4.79$ & 0.027 \\
\hline $\mathrm{RF}(\mathrm{mg} / \mathrm{dL})$ & $3.79 \pm 0.86$ & $3.09 \pm 1.10$ & 0.017 \\
\hline Anti-CCP antibody (u/mL) & $27.56 \pm 4.39$ & $17.60 \pm 4.42$ & \\
\hline
\end{tabular}

Table 3: Mean vitamin D levels in the study population

\begin{tabular}{llll}
\hline & $\begin{array}{l}\text { Case } \\
(\text { mean } \pm S D)\end{array}$ & $\begin{array}{l}\text { Control } \\
\text { (mean } \pm S D)\end{array}$ & $p$-value \\
\hline $\begin{array}{l}\text { Vitamin D level } \\
(\mathrm{ng} / \mathrm{mL})\end{array}$ & $18.41 \pm 7.10$ & $22.32 \pm 4.80$ & $<0.05$ \\
\hline
\end{tabular}

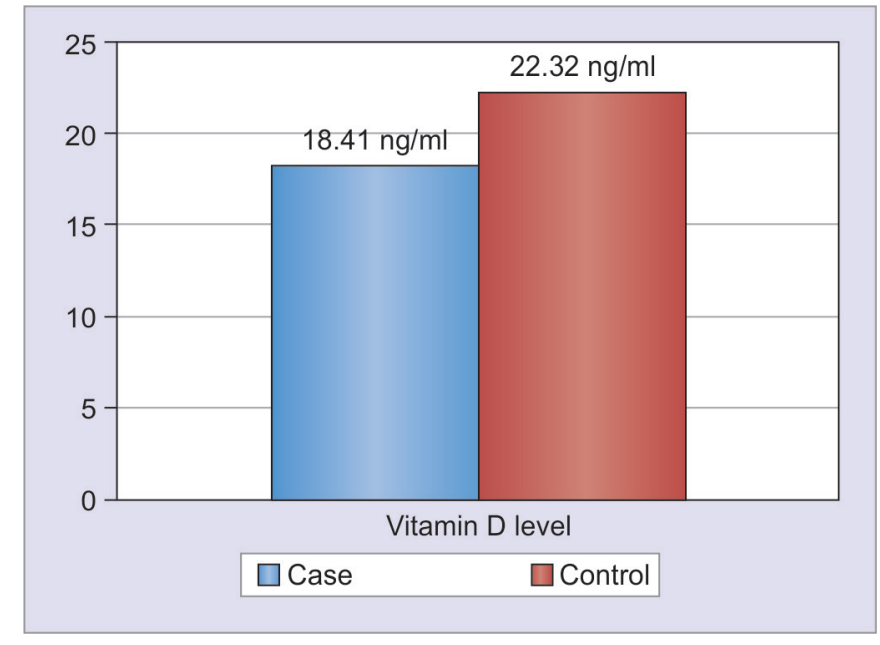

Graph 1: Mean vitamin D levels in the study population

Table 4: Mean vitamin D levels in the corresponding groups of RA disease severity (as per DAS-28 severity)

\begin{tabular}{lll}
\hline Severity of disease activity & $\begin{array}{l}\text { Number of } \\
\text { cases }(\%)\end{array}$ & $\begin{array}{l}\text { Vitamin D level } \\
(\text { mean } \pm \text { SD) }\end{array}$ \\
\hline Low & $4(16.0 \%)$ & $22.75 \pm 2.98$ \\
Moderate & $15(60.0 \%)$ & $16.6 \pm 3.36$ \\
High & $6(24.0 \%)$ & $6.07 \pm 2.26$ \\
\hline
\end{tabular}

- DAS-28 score 3.2 to 5.1 moderate disease activity

- DAS-28 score $<3.2$ low disease activity.

\section{DISCUSSION}

Given the enthusiasm in correlation of vitamin D deficiency and many autoimmune rheumatic diseases, we studied this 
in RA and found that demographic parameters such as age, gender, and BMI were statistically nonsignificant. Female patients were more in both groups. Similar observation was made in the study done by Yassin et al. ${ }^{12}$ The mean age was $35.36 \pm 3.18$ years in cases and $34.52 \pm 3.17$ in control group in our study population (Table 1). Although female gender was found to be predisposing factor contributing to vitamin D deficiency in a study in Morocco, in our study it was statistically insignificant. ${ }^{13}$ In our study, both the large and small joints were involved. There was no predilection of smaller joint involvement. In our patient population, according to DAS-28, there were four cases with low disease activity, 15 with moderate disease activity, and 6 cases of high disease activity. We found mean vitamin D levels to be low in the group of patients with RA as compared with controls (Table 3). Similar findings were noted in the study by Yassin et al. ${ }^{12}$ Their study results showed that 25-hydroxy $(\mathrm{OH})$ vitamin D levels were significantly lower in patients with RA compared with healthy controls. Additionally, vitamin D levels were lower in the patients with RA with high disease activity than in those with low disease activity. Likewise, they found that there was significantly inverse correlation between serum $25-\mathrm{OH}$ vitamin $\mathrm{D}$ levels and RA disease activity as assessed by DAS-28 score, which is similar to our study. In a study from Morocco, total 170 patients with mean age of $50 \pm 12.1$ years and predominantly female patients were enrolled with the objective to evaluate the prevalence of vitamin $\mathrm{D}$ insufficiency in patients with RA, and in association with disease activity, they found vitamin $\mathrm{D}$ deficiency in $35.5 \%$ of cases and insufficiency in $64.5 \%$ of cases. Female gender, asthenia, and severity of RA were the main factors responsible. ${ }^{13}$ Orbach et $\mathrm{al}^{14}$ indicated that patients with various autoimmune diseases had lower levels of $25-\mathrm{OH}$ vitamin D level than healthy adults. On the contrary, a recent study did not find a correlation between vitamin $\mathrm{D}$ deficiency and RA disease activity. ${ }^{15}$

Braun-Moscovici et $\mathrm{al}^{16}$ found high incidence of vitamin D deficiency in inflammatory joint disease (IJD) patients. They suggested inclusion of vitamin $\mathrm{D}$ in the routine biochemical work-up of patients with IJD. We found an inverse association between vitamin $\mathrm{D}$ levels and RA disease activity. Several studies have evaluated the association between vitamin D levels and RA activity. Haque and Bartlett ${ }^{17}$ found an inverse relationship between vitamin $\mathrm{D}$ levels and disease activity in RA. Similar conclusion was echoed by Cutolo et $\mathrm{al}^{18}$ in their study. These studies emphasize the role of vitamin D in immune regulation. Vitamin D induces immunologic tolerance. ${ }^{19}$ It regulates the immune response by a variety of mechanisms, such as decreasing antigen presentation, inhibiting the proinflammatory T-helper type 1 profile, and inducing regulatory T cells. The 1,25-dihydroxyvitamin D3 suppresses proliferation and immunoglobulin production and retards differentiation of B-cell precursors into plasma cells as reported by Chen et al. ${ }^{7,20,21}$ Supplementation with vitamin $\mathrm{D}$ has been advocated as a means to induce immune tolerance and thus prevent the development of autoimmune diseases. $^{22}$ In a study, Deal ${ }^{23}$ observed that the patients with RA are prone to osteoporosis. Vitamin D supplementation may help in prevention and treatment of osteoporosis as well as may help in modulating disease activity in RA. ${ }^{24}$

\section{CONCLUSION}

It is thus concluded that in RA patients, the serum vitamin $\mathrm{D}$ levels were found to be significantly lower than in healthy controls, and vitamin D deficiency may be one of the causes leading to development of worsening of RA. As the inflammatory burden increases in RA, the levels of vitamin D are reduced, which shows immunomodulatory activity of vitamin D. It is further suggested that vitamin D supplementation in this group may reduce RA activity.

\section{REFERENCES}

1. Jagtap S, Turankar AV, Bankar MA, Jaiswal KM, Motghare VM, Urade C, Pawar S, Jadhav M, Magdum A. Status of serum vitamin D levels in patients of rheumatoid arthritis: a pilot study. J Rational Pharmacother Res 2014 Apr;2(3):90-95.

2. Cross M, Smith E, Hoy D, Carmona L, Wolfe F, Vos T, Williams B, Gabriel S, Lassere M, Johns N, et al. The global burden of rheumatoid arthritis: estimates from the Global Burden of Disease 2010 study. Ann Rheum Dis 2014 Feb;73(7):1316-1322.

3. Kamen DL, Cooper GS, Bouali H, Shaftman SR, Hollis BW, Gilkeson GS. Vitamin D deficiency in systemic lupus erythematosus. Autoimmun Rev 2006 Feb;5(2):114-117.

4. Pelajo CF, Lopez-Benitez JM, Miller LC. Vitamin D and autoimmune rheumatologic disorders. Autoimmun Rev 2010 May;9(7):507-510.

5. Ingraham BA, Bragdon B, Nohe A. Molecular basis of the potential of vitamin D to prevent cancer. Curr Med Res Opin 2008 Jan;24(1):139-149.

6. Jones BJ, Twomey PJ. Issues with vitamin D in routine clinical practice. Rheumatology (Oxford) 2008 Sep;47(9):1267-1268.

7. Chen S, Sims GP, Chen XX, Gu YY, Chen S, Lipsky PE. Modulatory effects of 1,25-dihydroxy-vitamin D3 on human B cell differentiation. J Immunol 2007 Aug;179(3):1634-1647.

8. Laragione T, Shah A, Gulko PS. The vitamin D receptor regulates rheumatoid arthritis synovial fibroblast invasion and morphology. Mol Med 2012 Mar;18:194-200.

9. Szeto FL, Sun J, Kong J, Duan Y, Liao A, Madara JL, Li YC. Involvement of the vitamin $\mathrm{D}$ receptor in the regulation of NF-kappaB activity in fibroblasts. J Steroid Biochem Mol Biol 2007 Mar;103(3-5):563-566.

10. Holick MF, Chen TC. Vitamin D deficiency: a worldwide problem with health consequences. Am J Clin Nutr 2008 Apr;87(4):1080S-1086S.

11. Thomas MK, Lloyd-Jones DM, Thadhani RI, Shaw AC, Deraska DJ, Kitch BT, Vamvakas EC, Dick IM, Prince RL, Finkelstein JS. Hypovitaminosis D in medical inpatients. N Engl J Med 1998 Mar;338(12):777-783. 
12. Yassin A, Gareeb H, Mohamed NA, Samy C. The relationship between vitamin $\mathrm{D}$ and disease activity in Egyptian patients with rheumatoid arthritis. Int Trends Immun 2014 Jul;2(3):122 127.

13. Abourazzak FE, Talbi S, Aradoini N, Berrada K, Keita S, Hazry T. 25-hydroxy vitamin $\mathrm{D}$ and its relationship with clinical and laboratory parameters in patients with rheumatoid arthritis. Clin Rheumatol 2015 Feb;34(2):353-357.

14. Orbach H, Zandman-Goddard G, Amital H, Barak V, Szekanecz Z, Szucs G, Danko K, Nagy E, Csepany T, Carvalho JF, et al. Novel biomarkers in autoimmune diseases; prolactin, ferritin, vitamin $\mathrm{D}$, and TPA levels in autoimmune diseases. Ann NY Acad Sci 2007 Sep;1109:385-400.

15. Baker JF, Baker DG, Toedter G, Shults J, Von Feldt JM, Leonard MB. Associations between vitamin D, disease activity, and clinical response to therapy in rheumatoid arthritis. Clin Exp Rheumatol 2012 Sep-Oct;30(5):658-664.

16. Braun-Moscovici Y, Toledano K, Markovits D, Rozin A, Nahir A, Balbir-Gurman A. Vitamin D level: is it related to disease activity in inflammatory joint disease? Rheumatol Int 2011 Apr;31(4):493-499.

17. Haque UJ, Bartlett SJ. Relationships among vitamin D, disease activity, pain and disability in rheumatoid arthritis. Clin Exp Rheumatol 2010 Sep-Oct;28(5):745-747.
18. Cutolo M, Otsa K, Laas K, Yprus M, Lehtme R, Secchi M, Sulli A, Paolino S, Seriolo B. Circannual vitamin d serum levels and disease activity in rheumatoid arthritis: Northern versus Southern Europe. Clin Exp Rheumatol 2006 NovDec;24(6):702-704.

19. Weiss ST. Bacterial components plus vitamin D: the ultimate solution to the asthma (autoimmune disease) epidemic? J Allergy Clin Immunol 2011 May;127(5):1128-1130.

20. Mora JR, Iwata M, von Andrian UH. Vitamin effects on the immune system: vitamins A and D take centre stage. Nat Rev Immunol 2008 Sep;8(9):685-698.

21. Hewison M. Vitamin D and immune function: autocrine, paracrine or endocrine? Scand J Clin Lab Invest Suppl 2012 Apr;243:92-102.

22. Bartley J. Vitamin D: emerging roles in infection and immunity. Expert Rev Anti Infect Ther 2010 Dec;8(12):1359-1369.

23. Deal C. Bone loss in rheumatoid arthritis: systemic, periarticular, and focal. Curr Rheumatol Rep 2012 Jun;14(3):231-237.

24. Varenna M, Manara M,Cantatore FP, Del PuenteA, DiMunnoO, Malavolta N, Minisola G, Adami S, Sinigaglia L, Rossini M. Determinants and effects of vitamin D supplementation on serum 25-hydroxy-vitamin D levels in patients with rheumatoid arthritis. Clin Exp Rheumatol 2012 Sep-Oct;30(5): 714-719. 